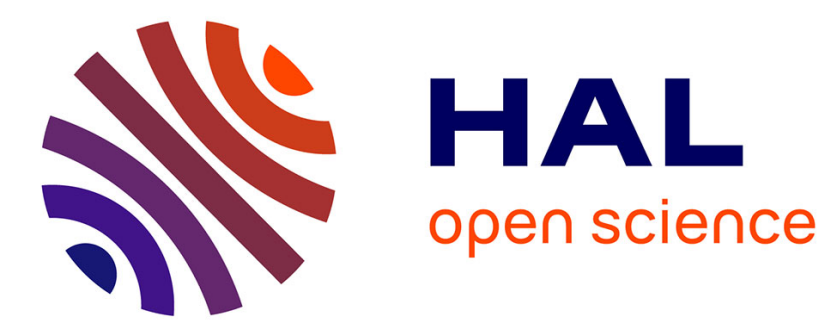

\title{
THE ORDINATION OF DGE SLONG MA: A CHALLENGE TO RITUAL PRESCRIPTIONS?
}

Nicola Schneider

\section{To cite this version:}

Nicola Schneider. THE ORDINATION OF DGE SLONG MA: A CHALLENGE TO RITUAL PRE-

SCRIPTIONS?. Revisiting Rituals in a Changing Tibetan World, 2012. hal-03210269

\section{HAL Id: hal-03210269 \\ https://hal.science/hal-03210269}

Submitted on 27 Apr 2021

HAL is a multi-disciplinary open access archive for the deposit and dissemination of scientific research documents, whether they are published or not. The documents may come from teaching and research institutions in France or abroad, or from public or private research centers.
L'archive ouverte pluridisciplinaire HAL, est destinée au dépôt et à la diffusion de documents scientifiques de niveau recherche, publiés ou non, émanant des établissements d'enseignement et de recherche français ou étrangers, des laboratoires publics ou privés. 


\title{
THE ORDINATION OF DGE SLONG MA: A CHALLENGE TO RITUAL PRESCRIPTIONS? ${ }^{1}$
}

\author{
NiCOLA SCHNEIDER \\ Université de PARis X-NANTERre
}

For the last twenty years, discussions on the institution of full ordination for women have been recurrent in the Tibetan exile community. The controversial debate and consecutive works of research show the importance Tibetans attach to ritual prescriptions, notably when it is a matter of rituals governed by the code of monastic discipline ('dul ba; Skt. vinaya) attributed to the Buddha himself. In this article I propose to examine some of the attitudes held and arguments put forward by the different protagonists over the years. These raise a number of questions pertinent to the 'Tibetan tradition' since the latter has come into contact with other cultures and by means of this with 'modern' ideas.

In Tibetan monasticism, nuns ( $a$ ne, jo mo, chos lags or dge ma) are only semi-ordained, that is, they take only the thirty-six vows of a dge tshul ma (literally 'one who has virtuous behaviour'; see Table 1). ${ }^{2}$ It is commonly accepted that full female ordination-the taking of the 364 vows of a dge slong $m a$ (literally 'one who inspires virtue') - has never existed in Tibet, since Indian nuns never came to transmit a lineage of fully-ordained women. However, in the texts of the monastic discipline of the Mūlasarvāstivādin school ( gzhi thams cad yod pa smra ba'i sde), which Tibetans adopted when monasticism was introduced to Tibet in

${ }^{1}$ I would like to thank Katia Buffetrille for her many corrections and rereads. My thanks also go to Anne-Marie Blondeau, Alexander von Rospatt and Jampa Tsedroen for their suggestions, and to Tashi Tsering, director of the Amnye Machen Institute in Dharamsala, for having generously communicated recent publications in Tibetan.

Tibetan names and terms are transliterated here according to the Wylie system. However, the names of the Tibetan authors of English-language works are presented as they appear in their publications.

2 Some researchers translate dge tshul ma as 'novice'. This Christian term implies that the nun in question is a beginner or somehow inexperienced. Since this is not true for most of the Tibetan dge tshul ma, I prefer to keep the original term.

In the bka' brgyud school, nuns generally only take the five vows of an ordained layperson (information given by the Karmapa to Jampa Tsedroen) 
the $8^{\text {th }}$ century, we find all the ritual rules and procedures for conferring full female ordination. According to these rules, ordination must be preceded by a 'two-year training period' during which the candidate observes twelve preliminary vows (six "root" tenets' [rtsa ba'i chos drug] and six " "associated" tenets' [rjes mthun gyi chos drug]) in addition to the vows of a dge tshul ma. She is then called dge slob ma, female religious trainee (literally 'one who studies virtue'). In the Tibetan tradition, the minor ordination of a woman is conferred by a fully ordained monk and in this way the candidate joins the monastic community. ${ }^{3}$ Full ordination, on the other hand, according to the vinaya rules of the Mūlasarvāstivādin, requires the intervention of the "dual monastic community" (dge 'dun sde gnyis), that is to say, monks and nuns. In the absence of fully-ordained nuns, the full ordination cannot, therefore, take place. A question then arises: how is it possible to institute the ordination of dge slong ma for Tibetan nuns? Can the ritual procedures be modified? And if so, how can such a change be legitimised?

In the last twenty years, important changes have taken place in the religious life of Tibetan nuns both in exile and in Tibet proper. Thus, and contrary to the past, nuns today have access to higher studies, they participate in rituals formerly reserved for the male clergy, such as the 'Great Prayer' (smon lam chen mo) and the bimonthly 'confession ceremony' (gso sbyong), ${ }^{4}$ and most of their institutions now function independently from those of monks. To achieve this step and to obtain a status genuinely equal to that of monks, some Tibetan nuns in exile, encouraged by their Western 'sisters', wish to institute full ordination for women in the Tibetan tradition. They are supported by the Dalai Lama, who has continually repeated that full female ordination would be beneficial for Tibet, since this would realise the 'fourfold Buddhist community' (lay followers of the two sexes, dge slong and dge slong $m a)$ that would make Tibet a 'central land' (yul dbus) of Buddha's teachings. However, he has also emphasised the necessity to conduct preliminary investigations to find a means to accomplish this in accor-

\footnotetext{
3 Contrary to Theravāda Buddhist countries such as Thailand where nuns only have access to the vows of the laity and thus remain excluded from the monastic community.

${ }^{4}$ Most monks and nuns of the monasteries of Dharamsala meet in the main temple (gtsug lag khang) for this ceremony; dge tshul ma and dge tshul, however, take part in only the first part of the ritual act, whereas the second, the main one, is reserved exclusively for the dge slong.
} 


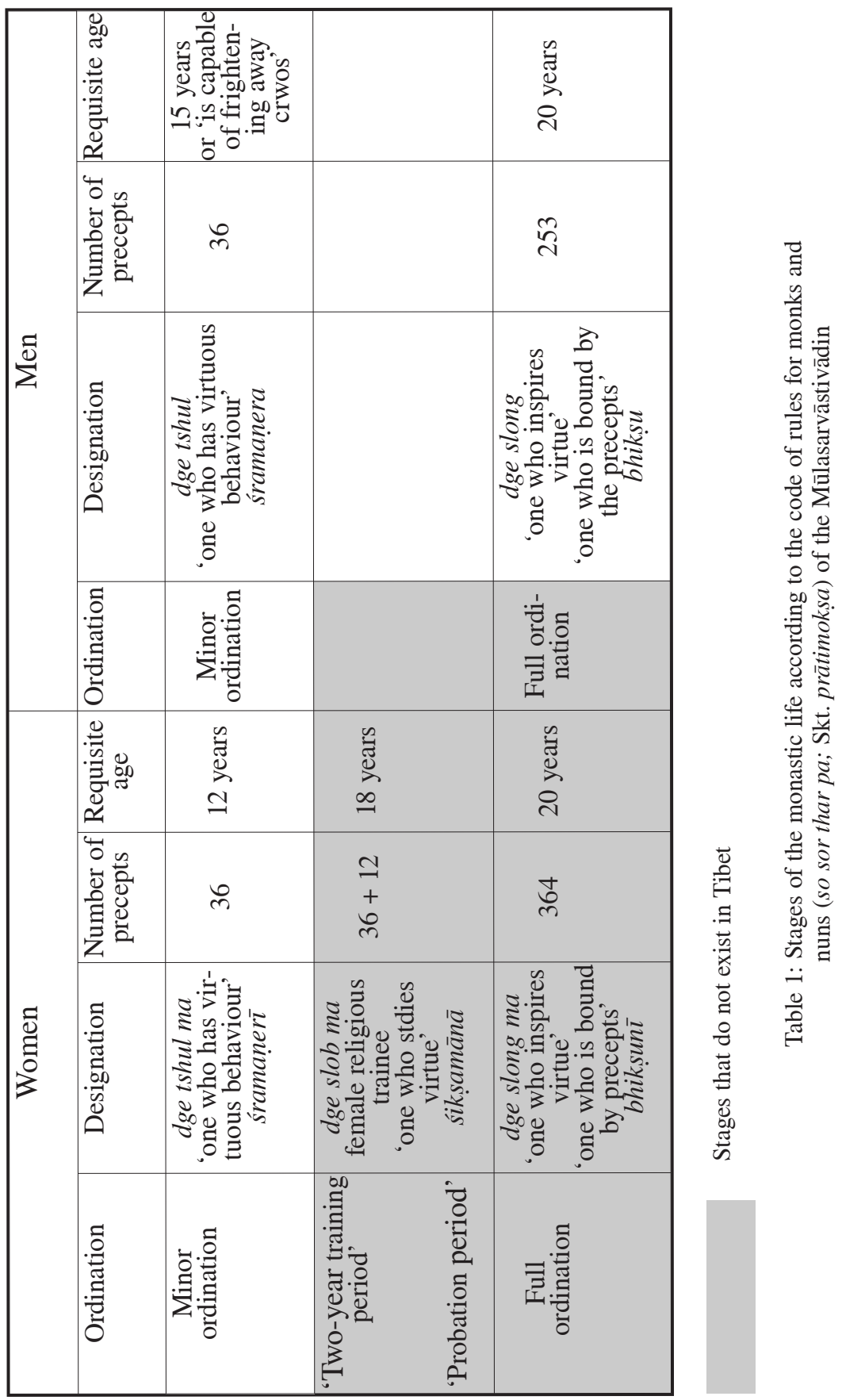


dance with monastic discipline, and then to hold discussions with Tibetan and other Asian monastic dignitaries in order to secure their approval. Such a decision, he maintains, cannot come from him alone but must be reached by consensus.

The present article is based on my research at Sgrol ma gling, a nunnery and institute of higher studies for women located near Dharamsala, in India, where I conducted fieldwork on several occasions between 1996 and 2005. Built in 1992, it is today the residence of around two hundred nuns, most of them originally from Tibet. For comparison, I will also refer to the nuns of Bkra shis dgon gsar, a nunnery in eastern Tibet (Mi nyag, in the Chinese province of Sichuan).

\section{CONTEXT}

Western nuns were the first to ask for full ordination. As they could not do this in the Tibetan Buddhist tradition they had adopted, from the 1970s on some of them went to Hong Kong to receive ordination in the Chinese tradition, that of the Dharmaguptaka. On the advice of Si tu Rinpoche (one of the great karma bka' brgyud hierarchs), a few Tibetan nuns, supported by the Hong Kong Kagyu Dharma Centre, followed their example: four made the journey to Hong Kong in 1984, followed by four more in $1987 .{ }^{5}$ Both the Western and Tibetan nuns were supported in their undertaking by the Dalai Lama, who in 1983 began publicly show his interest in female ordination. On several occasions during his visits to various nunneries in exile he encouraged nuns to continue on this path. However, success was only partial. Even though some Tibetan nuns were now fully ordained, they have achieved their goal in a tradition other than their own, and therefore do not have the right to officiate alongside Tibetan monks and nuns at times of important rituals, such as the bimonthly confession ceremony or the summer retreat (dbyar gnas); theoretically they must follow different ritual procedures. It is not very surprising that other nuns have not immediately followed their example and a solution had to be found to reintegrate into the Tibetan tradition these nuns who had been fully ordained in the Chinese Dharmaguptaka lineage.

\footnotetext{
${ }^{5}$ On the subject of the first-and, to my knowledge, the only-Tibetan nuns ordained as dge slong $m a$ cf. Havnevik (1995: 266-67).
} 
In 1987, a few Western nuns of the Tibetan tradition organised the first large international gathering of Buddhist nuns at Bodhgayā. This gathering gave birth to an association called Sakyadhita ('Daughters of the Buddha'). The Dalai Lama, who had been invited, made known his desire to discuss more generally women's rights and to "explore the potential of women within Buddhism". ${ }^{6}$ Since then, this association has become an important international Buddhist feminist movement, with the goal of raising the social status of Buddhist women, and to institute full ordination in every country where it does not exist. ${ }^{7}$ It has subsequently organised other conferences, in Thailand (1991), Sri Lanka (1993), Ladakh (1995), Cambodia (1997/1998), Nepal (2000), Taiwan (2002), Malaysia (2006), Mongolia (2008) and Vietnam (2009/2010). Numerous national and regional branches have been founded in Asia, the United States and Europe, each arranging its own meetings and conferences. ${ }^{8}$ In 1998, members of this movement took part in an international ceremony of full ordination at Bodhgayā, organised by a Taiwanese monastery and conducted under the auspices of three masters of the Chinese tradition, assisted by twenty-two masters from all the various Buddhist traditions. ${ }^{9}$

The Buddhist feminist movement started by Sakyadhita is complex in nature and the members' priorities differ according to their nationalities. I will cite only a few examples: in Asian countries, activities tend towards improving the status of women essentially by raising awareness of existing inequalities and by opening up education for women. For many Westerners, on the other hand, it is a question of putting into practice the 'egalitarian' teaching of the Buddha: Buddhism and feminism are perceived by some as 'two sides of the same coin', insofar as

${ }^{6}$ Karma Lekshe Tsomo (1988: 39).

7 On the Sakyadhita website (www.sakyadhita.org/index2.html, access date October 2007), the objectives are listed in the following order: "to promote world peace through the practice of the Buddha's teachings; to create a network of communications for Buddhist women throughout the world; to promote harmony and understanding among the various Buddhist traditions; to encourage and help educate women as teachers of Buddhadharma; to provide improved facilities for women to study and practice the teachings, and finally, to help establish the Bhikshuni Sangha (community of fullyordained nuns) where it does not currently exist".

8 Wurst (1999) estimates the number of Sakyadhita members at six hundred and those interested at 1,800. According to Gabriela Küstermann from Sakyadhita Germany, there were five hundred members in 2007—a slightly declining number-but two thousand interested parties.

${ }^{9} \mathrm{Li}$ (1999) gives a detailed description of this ordination ceremony. See also Gellner and LeVine (2005: 189-93). 
both tend towards liberation and change. ${ }^{10}$ The members of Sakyadhita, and notably the Westerners, are also particularly prolific in their writing: several conference proceedings have been published by the president of the association, Karma Lekshe Tsomo, a Hawaiian nun of the Tibetan tradition and founder of a nunnery in exile. ${ }^{11} \mathrm{~A}$ newsletter is published on Sakyadhita's website, as well as many other articles, either online or in journals and in the press.

Western nuns have exercised a certain influence over Tibetan nuns. Through their founding and financing of several nunneries in exile, they have conveyed some of their feminist ideas. ${ }^{12}$ It is in this context that the Tibetan Nuns Project (bod kyi btsun ma'i las 'char) was born in 1987. Founded by Rinchen Khando Choegyal (Rin chen mkha' 'gro chos rgyal), the sister-in-law of the Dalai Lama, Lobsang Dechen (Blo bzang bde chen, a Tibetan nun), and Elizabeth Napper, an American Buddhologist - all three former members of the Tibetan Women's Association (bu med tshogs pa) - this new association first of all directed its efforts towards the improvement of the living conditions of Tibetan nuns in exile, mostly those recently arrived from Tibet. Two new nunneries were founded in India: Sgrol ma gling and Shug gseb. The association then helped to introduce new study programmes in almost all the nunneries in exile in order to allow nuns to obtain degrees traditionally reserved for men, like the prestigious dge lugs pa title of dge bshes, 'doctor of traditional (Buddhist) philosophy' or that of the rnying ma pa, mkhan po.

${ }^{10}$ Cf. Anderson (1997). Western Buddhist nuns are trying to introduce a feminist current that one also finds in Christian theology in the West, see for example Chaves (1997). More generally, on the interest shown in the United States in Buddhism and its practices by some feminist spiritual movements, see for example Gross (1981).

11 The editor of at least eight books containing articles on full female ordination (1988, 1995, 2000, 2004a, 2004b, 2004c, 2006 and 2008) and a comparative work on the code of rules for nuns in the Tibetan tradition and the Chinese tradition (1997), Karma Lekshe Tsomo has lived and studied Buddhism in the Tibetan community in exile for fifteen years. After having founded 'Jam dbyangs chos gling nunnery, she created the Jamyang foundation, which introduced study programmes for nuns in six other institutions in Ladakh, Spiti and Kinnaur. She is today associate professor in the Department of Theology and Religious Studies at the University of San Diego where she teaches Buddhism, World Religion and Comparative Religious Ethics.

12 Freda Bedi, another Western nun, has founded the nunnery Karma sgrub brgyud dar rgyas gling at Tilokpur, India (cf. Havnevik op. cit.: 139). Still others, like for example Dge ldan chos gling and Byang chub chos gling, have received significant financial assistance thanks to the commitment of Western nuns. 
Supported by the Dalai Lama and with the backing of some Western nuns, those in charge of the association have at the same time begun to tackle the subject of full ordination by first addressing the Department of Religion and Culture (bod gzhung chos rig las khungs), the official authority of the Tibetan government in exile that administers religious affairs. From the beginning, reluctance was great: a circular sent to fifty-five Tibetan hierarchs asking them to express themselves on the institution of full female ordination elicited only eleven responses, five in favour and six against. ${ }^{13}$ Likewise, two religious conferences organised under the auspices of the Department of Religion and Culture in 1993 and 1995 proved to be unsuccessful, the participants being insufficiently acquainted with the subject and lacking reliable sources. The Dalai Lama then decided to create a committee of scholars charged with collecting materials and references necessary in order to take a decision. However, only Geshe Tashi Tsering (Dge bshes Bkra shis tshe ring), who at that time was working in the Department of Religion and Culture, took the subject to heart and continued to pursue his research on full female ordination. ${ }^{14} \mathrm{He}$ went to Taiwan in 1997 to gather information on the Chinese lineage and attended the ordination ceremony at Bodhgayā in 1998. He then presented the results of his research at a seminar which took place in August 1998 at Nor bu gling ka (Dharamsala). Religious dignitaries from the three vinaya schools (the Mūlasarvāstivāda, the Theravāda and the Dharmaguptaka) participated. The results of this seminar were published in three volumes by the Department of Religion and Culture. ${ }^{15}$ The essential points were as follows:

1. No dge slong ma lineage was transmitted to Tibet when monastic lineages were introduced;

2. Several attempts to ordain women in Tibet have taken place in the past, for example those of 'Gro mgon chos rgyal 'Phags pa (1235-1280) and Pan chen Shākya mchog ldan (1428-1507), but they were subsequently challenged;

3. In the Vinayamülasütra ('dul ba'i mdo rtsa ba), an extensive treatise on the monastic discipline which summarises the essential meaning of

13 Thubten Chodron (1994: 39).

14 From the 1980s, the Dalai Lama has charged Geshe Tashi Tsering with researching the subject of female ordination. The later published, at that time, an article in English (Acharya Tashi Tsering and Russell, 1986).

15 Cf. Department of Religion and Culture 2002 and Ācārya dge bshes Thub bstan byang chub, alias Geshe Tashi Tsering (2000a, 2000b, 2000c). 
the four Vinayasütra, it is stated that full ordination for women must be preceded by a 'two-year training period';

4. Finally, the other two Asian lineages were also examined, with the conclusion that there is no uninterrupted Theravāda lineage of fully ordained nuns. On the other hand, there is a living lineage among the Dharmaguptaka in China, Taiwan and Korea, but its validity remains to be determined.

These publications were then sent to two hundred key Tibetan figures (vinaya masters, lamas, nuns and scholars) with the request that they comment on them. However, in spite of repeated reminders, only thirteen responses were obtained. They did not present a unanimous opinion.

\section{THE DILEMMA FOR TIBETAN NUNS}

Faced with the silence of the Tibetan dignitaries, the Tibetan Nuns Project decided to rethink its strategies and to prepare the nuns better. When the various exchanges were taking place, it became clear that to succeed, the nuns would first have to demonstrate exemplary behaviour, as much in the strict observance of monastic discipline as in the pursuit of their studies. Their level of studies still being insufficient at that time, it seemed more judicious to pursue their training before taking up the discussions again.

At Sgrol ma gling, the leading institute for the Tibetan Nuns Project — which, as such, serves as its seat - the rhythm of studies was accelerated from that time. The distinctive feature of this institute is that it offers a non-sectarian approach to Buddhism in integrating into its curriculum teachings stemming from all four of the great Tibetan traditions. Its main objective, however, consists of preparing nuns one day to obtain the title of dge bshes (dge bshes ma in the feminine) through a proposed programme modelled on that of the great Tibetan monastic universities (Dga' ldan, 'Bras spungs and Se ra).

Most of the nuns at Sgrol ma gling have already received minor ordination before joining this nunnery, either in Tibet proper or in exile. Ordination ceremonies are not celebrated at Sgrol ma gling, as in most other nunneries in exile. Not only are there no monks competent to conduct the ritual, most of the candidates these days wish to take their vows from the Dalai Lama: once or twice a year, he personally confers ordi- 
nations (minor as well as full) during collective ceremonies organised by his private office, and the directors of Sgrol ma gling then organise the travel for the candidates who wish to participate.

Although candidates for minor ordination are not expected to have an experience of religious life or thorough knowledge of the rules of discipline to follow, many Tibetan monasteries today consider it desirable to prepare their new recruits. For this reason, many offer teachings in the rules of discipline. At Sgrol ma gling the nuns study the 'instructions for the dge tshul' in the form of a course in the first year. The text they use has been devised by and for monks, ${ }^{16}$ but since the number and the content of the rules are the same at this level, they consider that the nuns can also conform to them. ${ }^{17}$ Moreover, even students who have already received ordination some years previously think this course is useful because it allows them to better understand how to match their behaviour to the monastic statues. Others have confided to me their difficulty in integrating certain rules into their daily lives, such as the prohibition against taking meals after midday, or the requirement to sleep in the position of the Buddha-that is, on the right side-without ever turning during the night. Because the studies at Sgrol ma gling require a great deal of effort, concentration and perseverance, some obligations have not been applied to the letter by the nuns. Some nuns have admitted for this same reason that the observance of the rules of a fullyordained nun could prove to be a further constraint, not only in the pursuit of studies but also for their daily life in general: as one nun explained, it would be difficult to travel using public transport if one wanted to abide by the rule forbidding contact with the opposite sex.

Generally speaking, the nuns of Sgrol ma gling do not have a good knowledge of the rules that fully-ordained nuns must follow. Not having received the ordination themselves, theoretically they do not have the right to undertake an in-depth study of the code of conduct of a dge slong $m a$.

Since the end of the 1990s, the Tibetan Nuns Project has established contacts with women's organisations from other Buddhist countries in order to inquire into and learn about measures taken elsewhere.

16 This is the text Kā ri kā lnga bcu pa dang de'i mchan 'grel nor bu'i phreng ba by Mi pham Rinpoche (1846-1912).

${ }^{17}$ It is interesting to note that although there is no systematic teaching of monastic rules at Bkra shis dgon gsar, in Tibet booklets on the 'instructions for dge tshul' circulate among some nuns. For the most part, related monks have given them to them. 
Lobsang Dechen, co-director of the association, accompanied in turn by nuns from Sgrol ma gling, has taken part in conferences organised by Sakyadhita and has expressed her wish on these and other occasions to institute full ordination in the Tibetan tradition. She also initiated exchanges with a Thai movement, the International Women's Partnership for Peace and Justice, when a conference was organised by the latter in Bangkok in 2002. Two Thai trainers from this organisation were subsequently invited to different Tibetan nunneries in exile to lead workshops with the objective to prepare nuns to 'assume a position of leadership in the field of spirituality, social activity and feminism'.

These various exchanges have allowed Tibetan nuns in exile to enhance their knowledge of the outside world and to understand the issues from a feminist point of view, both Western and Asian. However, this is not to say that they share completely this vision or that they have adopted the more militant attitudes and claims of their sisters. Brought up to present themselves as obedient, humble and modest vis-à-vis their masculine superiors, many nuns do not wish to press them on these matters but deem it more desirable to obtain their consent and their support. ${ }^{18}$

Interestingly, there is no debate on the institution of full ordination for women at Bkra shis dgon gsar, the nunnery in Mi nyag where I was able to stay in 2002 and $2003 .{ }^{19}$ This can be explained by the fact that this monastery follows the rnying $\mathrm{ma}$ school, for which monastic discipline generally plays a less important role. But the principal reason is that the nuns there are too preoccupied with the re-establishment of the religious life and by the constant concern for safeguarding what they have regained thus far. In this regard, they are in contact with nuns and monks of surrounding monasteries. In this way, also, they have learned that their exiled sisters today have the possibility of pursuing higher studies, a goal that they share. Their lama, A khu 'Brug grags rgya mtsho, regularly travels to mainland China to give teachings, and two

18 More generally, Tibetan women do not seem to demand gender equality. On the contrary, for several of my informants, male and female alike, it is the gender difference that is fundamental: according to them, women require more specific protection, for example, when they go for a walk alone, because they are then in danger. It is also interesting to note that the Tibetan Women's Association has emphasised the fact that it distinguishes itself from other women's associations or movements because it does not advocate gender equality (Seele-Nyima 2001: 379).

19 To my knowledge, full female ordination is not a subject of discussion among the nuns in Tibet proper. 
Chinese monks live with him in the monastery. But these contacts are unilateral: they are aimed solely at spreading Tibetan Buddhism-in return for donations, sometimes considerable - and not to integrate elements of Chinese Buddhism. Nevertheless, if one looks closely at the history of Mi nyag, it is also one of the rare Tibetan regions where there is proof of the existence of fully ordained nuns: in the $14^{\text {th }}$ century, a group of dge slong $\mathrm{ma}$ were among the disciples of a great local scholar, Mkhan chen Bka' bzhi pa chen po Rig pa'i seng ge. ${ }^{20}$ But this remains little known locally. It is interesting to note as well that religious authorities, such as Gzan dkar Rinpoche Thub bstan nyi ma, spiritual head of the region and an internationally-known researcher, and 'Jam dbyangs grags pa, monk and professor of Tibetan medicine, do not regard this dge slong ma community as a precedent with any modern relevance. ${ }^{21}$

Let us now return to the nuns of Sgrol ma gling and to the immediate utility that the institution of full ordination would have for them. In the framework of their studies intended to lead them to the title of $d g e$ bshes $m a$, they are supposed to study monastic discipline in its entirety. For that, as we have seen, they would first need to receive full ordination, which confers the necessary authorisation to go more deeply into the study of these texts. At the end of 2003, the most advanced students successfully undertook the study of the Perfection of Wisdom (phar phyin). The following year, they started on that of the Middle Way ( $d b u m a$ ), which takes about two years and which precedes the section on the vinaya ('dul ba). It was then that those in charge of the Tibetan Nuns Project worried about the organisation of the continuation of their training: it became urgent to resolve the problem of the institution of full ordination. In view of the difficulties encountered, the question also arose of knowing if the study of the vinaya might not be shortened or replaced by something else.22 But this idea was then rejected because of the risk that a dge bshes diploma obtained in this way would be depreciated by both the clergy and the laity. ${ }^{23}$

20 Mkhan chen bka' bzhi pa chen po rig pa'i seng ge'i rnam thar pa yon tan rinpoche'i rgya mtsho (1287-1375) see his biography in Thub bstan nyi ma (1987: 71-72).

21 From conversations with Gzan dkar Rinpoche and 'Jam dbyangs grags pa. In his article, which summarises the biography of Mkhan chen Bka' bzhi pa chen po Rig pa'i seng ge, 'Jam dbyangs grags pa (1986) does not mention any dge slong ma disciples.

22 In Byang chub chos gling nunnery in Mundgod (south of India), study of the vinaya was reduced to the section of dge tshul ma vows (conversation with Jampa Tsedroen).

23 Some Tibetan scholars criticise the idea of giving the title of dge bshes to nuns, 
As far as the nuns of Sgrol ma gling are concerned, a significant number of them have left the nunnery at that time. Some chose to pursue their studies on another religious path, like meditation; others left for an institution that allowed them to become teachers or to work in a secular field, and some decided to leave the monastic life altogether. Thus the enthusiasm which has led the nuns, throughout the 1990s and to the beginning of this century, to hope that they might one day obtain the title of dge bshes was considerably dampened.

\section{THE RESUMPTION OF THE DEBATE}

Those in charge of the Tibetan Nuns Project, however, remain positive. The director and sister-in-law of the Dalai Lama, Rinchen Khando, explained to me in a conversation in April 2005 that, for her, the opportune time to restart the debate had come because nuns had shown by their determination to pursue the studies and to conform to the discipline, and that they were not only ready to obtain full ordination but that they also merited it. A little earlier, the Tibetan Nuns Project was contacted by Tenzin Palmo (Bstan 'dzin dpal mo) and another Western nun, both being in charge of the nunnery Dga' tshal gling, who also considered that the time had come again to tackle the subject of female ordination. They decided to set up a study committee consisting of Tibetan and Indian nuns, as well as few Western nuns from eight nunneries in exile. ${ }^{24}$ Their objective was to resume discussions with the Department of Religion and Culture, several members of which had changed in the meanwhile. Tibetan dignitaries from various schools, such as Pad nor Rinpoche, Sa skya khri 'dzin, 'Dri gung skyabs mgon Che tshang Rinpoche and Mkha' 'gro Rinpoche gave them moral support. ${ }^{25}$

arguing that it is a diploma which only the three great monastic universities (Dga' ldan, 'Bras spungs and Se ra) can traditionally confer. Cf. 'Ba' pa Skal bzang 'phrin las 'Bras blo gling (2007: 3).

24 These nunneries are Sgrol ma gling, Dge ldan chos gling, Shug gseb, Karma sgrub brgyud dar rgyas gling, Sa skya rin chen chos gling, 'Dri gung bsam gtan gling, 'Jam dbyangs chos gling and Byang chub chos gling.

25 Conversation with Philippa Russell. See also the letters of support published by the organisers of the 2007 international congress: http://www.congress-on-buddhistwomen.org/index.php?id=125 (access date October 2007). 
After several exchanges, a third seminar of vinaya specialists was organised in Dharamsala from 22 to 24 May 2006, and all the high Tibetan dignitaries and some representatives of the Tibetan government in exile were invited. But this meeting was again unsuccessful: the quorum necessary to adopt a resolution was not attained. Of those invited from the high clergy, only the Dalai Lama, the Karmapa, Zam gdong Rinpoche (then Prime Minister of the government in exile) and Geshe Tashi Tsering were present; the others apologised or sent a representative. In view of this meeting, a group of fully-ordained Western nuns who had set up their own committee (the Committee of Western Bhikshunis) had circulated a text requesting, in the name of all nuns of the Tibetan tradition, the re-establishment of full ordination. ${ }^{26}$ They also proposed a three-point discussion programme aimed at speeding up the taking of a decision:

1. Whether or not it is possible to establish full bhikșuñ ordination in accordance with the Mūlasarvāstivāda lineage that flourished in Tibet?

2. Whether or not there is a way for Tibetan nuns to get full bhiksuni ordination within the Dharmagupta vinaya tradition that flourished in China?

3. Whether or not there is an unbroken lineage of transmission within the system of vinaya that spread to Vietnam, as was told to His Holiness the Dalai Lama. ${ }^{27}$

In the introduction to their proposal, the authors justified their action with the statement that "Buddha gave equal opportunities to men and women" and "never made any discrimination between them" (ibid.), a declaration that seems to have been badly received. In his inaugural address, Zam gdong Rinpoche stated that on no account was it a matter for approaching the issue of ordination from the angle of redressing gender prejudice. ${ }^{28}$ Other participants reproached the Dalai Lama for being under the influence of Western nuns. ${ }^{29}$ The meeting then took a

26 This committee was set up at the request of the Dalai Lama in the autumn of 2005 and brings together the following Western dge slong ma: Bhikshuni Tenzin Palmo, Bhikshuni Pema Chodron, Bhikshuni Karma Lekshe Tsomo, Bhikshuni Thubten Chodron, Bhikshuni Jampa Tsedroen and Bhikshuni Ngawang Dolma.

27 The text presented can be found on:

www.thubtenchodron.org/.../a_means_to_achieve_bhiksuni_ordination.pdf (access date January 2009).

28 Cf. Central Tibetan Administration, press release of 23/05/2006.

29 Conversation with Tashi Tsering (Amnye Machen Institute) who participated in the seminar. 
virulent turn when the representatives of Sa skya khri 'dzin threw the whole project back into question, recalling that the full ordinations initiated by sa skya hierarchs in the past (and taking place exclusively before monks) had all been refuted at the same time by their contemporaries. ${ }^{30}$ With this intervention, they disagreed with their spiritual head, who had previously appeared favourable to the institution of female ordination. ${ }^{31}$

For lack of finding a consensus, this seminar revealed, above all, two opposed attitudes prevalent among some Tibetan dignitaries: a distrust of what was perceived as meddling on the part of Western nuns and the refusal to discuss a subject classified as closed. In these circumstances, it is perhaps not surprising that the Dalai Lama, principal defender of the nuns' cause, encouraged the Western nuns of the Committee of Western Bhikshunis to organise an international conference.

From 18 to 20 July 2007, the 'International Congress on the Role of Buddhist Women in the Monastic Community'32 took place in Hamburg, Germany. Organised by Jampa Tsedroen, a Western nun, and held at the University of Hamburg, this congress gathered together for the first time Buddhist dignitaries, followers and researchers from nineteen countries. The objective was to discuss with the present experts the different possibilities of instituting the dge slong ma lineage in the Tibetan tradition, and possibly inducing the Dalai Lama to reach a decision in favour of one of them. Without entering into the details of this conference, which I was unable to attend-some publications about the event have appeared in the meanwhile ${ }^{33}$ - it is, however, worth underlining the fact that there were not many Tibetan participants. It is also significant that most of those present had previously pronounced themselves in favour of the institution of full female ordination, such as the Dalai Lama, Geshe Tashi Tsering, Rinchen Khando and Lobsang Dechen.

At the end of the congress, two trends prevailed: while the dignitaries from the Theravāda tradition advocated the ordination of Tibetan nuns by Tibetan monks and nuns of the Chinese lineage, some Tibetan

30 Conversation with Tashi Tsering (Amnye Machen Institute).

31 It is not surprising that on the subject of the vinaya, the sa skya monks do not share the opinion of Sa skya khri 'dzin, since the latter is a married religious figure.

32 For further information, see the website: http://www.congress-on-buddhistwomen.org/ (access date October 2007).

33 Cf. Mohr and Jampa Tsedroen (2010). 
nuns expressed their desire to receive ordination by a congregation comprising only dge slong of the Mūlasarvāstivāda tradition..$^{34}$ In this way they sided with the proposal made by Geshe Tashi Tsering and Rin chen dngos grub which, as we shall see, is strongly criticised by other Tibetan vinaya specialists.

\section{THE DIVERGENT VIEWS OF THE TIBETAN CLERGY}

Before entering into the detail of different opinion, we should note the almost unanimous refusal of the Tibetan monastic community to involve nuns of the Chinese tradition, a solution nevertheless favoured by the international Buddhist community. For the Tibetans, the prohibition against mingling traditions goes back to the introduction of monasticism under the emperor Khri Srong lde btsan in the $8^{\text {th }}$ century, when the latter authorised the sole tradition of the Mūlasarvāstivādin in Tibet. Their argument is based on the refusal to allow the Indian Atiśa to establish his school, that of Mahāsamghika, in $11^{\text {th }}$ century Tibet..$^{35}$ However, recent research seems to indicate that this rule has not always been applied. During the congress in Germany, the American nun Thubten Chodron pointed out that in the $9^{\text {th }}$ century, at the time of the so-called persecution of Buddhism, three Tibetan refugee monks in Amdo solicited the aid of two Chinese monks to ordain the Tibetan Dgongs pa rab gsal. ${ }^{36}$ This act allowed them to continue their lineage, otherwise threatened with extinction. ${ }^{37}$ According to Thubten Chodron,

\footnotetext{
34 See the summary of the congress on the website of Berzin (2007): http://www.berzinarchives.com/web/x/nav/eb_toc.html_1717379581.html (access date October 2007).

35 Two texts are accepted as authoritative on this subject: the Religious history of Vinaya ('dul ba chos 'byung) by Pan chen Bsod nams grags pa (1478-1554) and the Ethics of Three Codes (sdom gsum rab dbye) by Sa skya pandita Kun dga' rgyal mtshan (1182-1251).

36 Thubten Chodron (2010).

37 Known by the name "lower lineage" (smad 'dul), it is one of the two lineages which have survived in Tibet. The second, called "central lineage" (dbus 'dul), was transmitted by the Kashmiri Sāāyaśrībhadra in the $12^{\text {th }}$ century, hence its name "lineage of the great scholar [Śākyaśrībhadra]" (pan chen sdom rgyun); it is subdivided into four branches (tshogs pa sde bzhi) (on this subject see also Jampa Tsedroen 2008: 209). 'Gro mgon chos rgyal 'phags pa and the Mi nyag lama, who conferred full ordination on women, both belong to this lineage (conversation with Tashi Tsering, Amnye Machen Institute). It would therefore be interesting to carry out further research on this particular lineage.
} 
this ordination could constitute a precedent which would authorise the intervention of nuns from the Chinese tradition. But at present her proposal is rejected by the majority of Tibetan dignitaries. ${ }^{38}$

\section{The defenders of full ordination for women}

If we trust the declarations done by Tibetans in English, it appears that besides the Dalai Lama, many religious dignitaries and politicians have come down in favour of female ordination. This is the case of the Karmapa, several ministers of the Tibetan government in exile, ${ }^{39}$ as well as some heads of religious lineages. ${ }^{40}$ At the inauguration of the Sgrol ma gling temple in 2005, bka' blon (Minister) Blo bzang nyi ma also gave assurances of his support and that of the Department of Religion and Culture. ${ }^{41}$ However, Geshe Tashi Tsering and Rin chen dngos grub seem, for the time being, to be the only Tibetan dignitaries to have pronounced themselves of a concrete solution on the institution of full ordination for women: both defend an ordination conferred by an assembly composed of monks only.

As a Tibetan researcher, Geshe Tashi Tsering has certainly made the most detailed analysis of the vinaya and of its commentaries written by Indian and Tibetan scholars. ${ }^{42} \mathrm{He}$ advances several arguments in favour of ordination conferred by monks only. First, he notes that the Buddha does not seem to have had the intention to lay down an exclusive method of ordination but that, quite the contrary, there were different means, of which three were practised for women. ${ }^{43}$ None of them, however, can be practised today: two necessitate the presence of dge slong

38 Thubten Chodron presented her findings beforehand at Rnam rgyal monastery (Dharamsala, India), where she received a great deal of criticism (conversation with Jampa Tsedroen). Does this reaction indicate that Tibetans monks are not ready to question the authenticity of their own ordination lineages?

39 Central Tibetan Administration, 23/05/2006.

${ }^{40}$ In spite of their absence at the congress in Germany, several hierarchs have written letters of support to the organisers. These include Sa skya khri 'dzin, the Karmapa, 'Dri gung skyabs mgon Che tshang Rinpoche, Rgyal dbang 'brug pa, Brag g.yab skyabs mgon Rinpoche, Si tu Rinpoche, Se ra byes rgyud smad mkhan zur O rgyan tshe brtan, Mkhan chen Khra 'gu Rinpoche and Se ra byes mkhan po dge bshes Blo bzang dpal ldan.

41 Central Tibetan Administration, 08/12/2005.

42 Apart from the three books cited in note 15, see also [Geshe] Tashi Tsering's article (2010).

43 Tashi Tsering (2010: 164). 
$m a$, a status which, as we have seen, does not exist currently in the Tibetan tradition; and the third is an exceptional case because it was the very first female ordination, that of Mahāprājapatī Gautamī, the aunt and adoptive mother of the Buddha, and her entourage of five hundred women who were ordained by adhering to the so-called 'eight heavy rules' (lci chos brgyad). ${ }^{44}$

Geshe Tashi Tsering's main argument is that women could be ordained by the way of the dge slong ordination ceremony. This point was suggested, he says, by the Buddha himself when he responded to questions posed by the nun Upalī: 45

"Noble One, if a male novice (dge tshul) is ordained [as a dge slong] by the dge slong ma ceremonial rite, is it considered being fully ordained?" "Upalī, it is called fully ordained; however, the performers of the ordination have infractions ('das pa)."

"Noble One, if a probationary nun (dge slob $m a$ ) is ordained by the dge slong ceremonial rite, is it considered being fully ordained?"

"Upalī, it is called fully ordained; however, the performers of the ordination have infractions."

According to Geshe Tashi Tsering, this dialogue was interpreted by some commentators of the monastic discipline as an authorisation given to monks to ordain nuns by the way of the monk rites and vice versa. "I6 "It is not [an invalid act] if dge slong and dge slong ma perform each other's rites", one reads, for example, in a passage of the Vinayasūtra ('Dul ba'i mdo). ${ }^{47}$ A commentary adds the following explanation:

"It is not [an invalid act] if dge slong and dge slong ma perform each other's rites" means if a dge slong is ordained by the dge slong ma rite, it is not unaccomplished [i.e, not invalid] and if a dge slong $m a$ is ordained by the dge slong rite, it is not unaccomplished. Neither the rite

44 The Buddha is said to have hesitated to accept women into the monastic community, but finally agreed by imposing them the "eight heavy rules". For more details and the consequences that this entails for nuns, who became in fact dependent upon their male counterparts, see, among others, Wijayaratna (1991) and Horner (1989).

45 Excerpt from the 'Dul ba gzhung bla ma (Bka' 'gyur) quoted by [Geshe] Tashi Tsering (2010: 169). Tibetan terms are given for the Sanskrit terms in the English translation of this article.

46 The sources to which Geshe Tashi Tsering refers here include commentaries by the famous Indian vinaya master Gunaprabhā, and by numerous Tibetan scholars such as Rong ston Smra ba'i seng ge rgyal mtshan (1367-1449), Go rams pa Bsod nams seng ge (1429-1489), Ngag dbang chos grags (1572-1641), among others.

47 Guṇaprabhā, 'Dul ba'i mdo (Bstan 'gyur) cited by Tashi Tsering (2010: 169). 
for the full ordination of dge slong nor the rite for the full ordination of dge slong $m a$ is ultimately the exclusive rite to be used for [its respective ordination alone $]. . .{ }^{48}$

Geshe Tashi Tsering has not been able to find in the Indian accounts an example where such a procedure has been followed. But in Tibet, there were few cases, such as the ordinations conferred by 'Gro mgon chos rgyal 'Phags pa and by Shākya mchog ldan mentioned above, as well as that of Chos kyi sgron ma, a Tibetan princess of the $15^{\text {th }}$ century who renounced the world and was subsequently considered as an emanation of the deity Rdo rje phag mo. ${ }^{49}$ However, because of harsh criticism, none of these ordinations has given rise to an ordination lineage.

Most of the critics in the past, like today, have been concerned by the 'two-year training period' and the subsequent rite (tshangs spyod nyer gnas), the pre-ordination rite requested for nuns, which should be conferred solely by a community of fully ordained nuns according to ritual prescriptions. Yet, those ritual masters like Shākya mchog ldan who have given full ordination to women considered that applying the dge slong rites to women allowed the 'two-year training period' to be waived. In order to discuss this particular point, Geshe Tashi Tsering proposed first to resolve the three points that long ago gave rise to the problem:

1. Whether or not it is appropriate to bestow the dge slong ma vow accompanied by an infraction through performing the dge slong ceremonial rite.

2. Whether [in this case] the tshangs spyod nyer gnas ordination is required beforehand.

3. Whether the tshangs spyod nyer gnas ordination can only be bestowed by the dge slong ma community or whether it may also be bestowed by the dge slong community when a [Mūlasarvāstivāda] dge slong ma community cannot be found. ${ }^{50}$

Geshe Tashi Tsering thus proposes a pragmatic solution without ignoring the instructions given in the Buddhist doctrine, according to which important matters should be resolved through discussion among vinaya holders. If Tibetan dignitaries could come to an agreement through dis-

48 [Geshe] Tashi Tsering (2010: 169). Quotation from the 'Dul ba'i mdo'grel pa mngon par brjod pa rang gi rnam par bshad pa (Bstan 'gyur) by Guṇaprabhā.

49 On Chos kyi sgron ma, see Diemberger (2007). Martin (2005: 67, 72-73) also gives two examples of fully ordained nuns.

50 [Geshe] Tashi Tsering (2010: 178-79). 
cussing these questions, a new lineage of dge slong ma in Tibet could be introduced without any external intervention.

Recently, the young dge bshes Rin chen dngos grub has shown interest in finding a solution to the institution of a lineage of dge slong ma. Having taught at Sgrol ma gling for a year, he then pursued his own studies at the tantric college of Rgyud stod. In June 2007, he published a book on the subject of dge slong $m a .^{51}$ Drawing inspiration from the research of Geshe Tashi Tsering, he also refers to a quotation from the 'summer retreat manual' (lung dbyar gyi gzhi) in which he sees a further justification for conducting the ordination ceremony with an assembly made up of monks only. It is written that the Buddha allowed dge slong to leave the summer retreat for seven days-after requesting permission in an appropriate manner-if they were asked to ordain a dge tshul ma or a dge slob ma, in spite of the usual prohibition on interrupting the retreat. According to Rin chen dngos grub, this passage implies that dge slong performed women's ordinations on their own, and thus corroborates the references revealed by Geshe Tashi Tsering, according to which ordination by monks alone is not an invalid act. Further, he considers that a refusal by the community of dge slong to perform full ordination for women would be an offence to the vinaya rules as well.

The participation of Rin chen dngos grub at the congress in Germany (2007) was badly received by some dignitaries who did not attend. They criticised him for having spread a slanted interpretation of the vinaya and, by extension, the Buddhist doctrine, which constitutes a serious offence according to the doctrine itself. Some of these criticisms have been published in the journal Tibet Express (Bod kyi bang chen $)^{52}$ and have in this way triggered a controversial debate. ${ }^{53}$ The question is far from being settled and we do not yet know who is going to prevail. Nonetheless, it is possible even at this stage to present some of the arguments advanced by the opponents.

51 Ser byes lha rams ngag gi dbang phyug Rin chen dngos grub (2007). This book was published with the help of the Tibetan Nuns Project and the Committee of Western Bhikshunis.

52 Published by the Kha ba dkar po Cultural Centre in India (Dharamsala) since 2003, this journal presents itself as the leading independent daily on Tibetan society. It brings together young writers and scholars who wish to engage in current discussions and debates on Tibetan society. See also the website: http://www.tibetexpress.net/.

${ }^{53}$ It is interesting to note that some authors use scholastic debate language, generally reserved for oral debates. 


\section{The opponents' criticism}

Most of the opponents of full ordination criticised Rin chen dngos grub, and Geshe Tashi Tsering as well, for sowing discord by spreading false interpretations of the vinaya texts. ${ }^{54}$ They accuse them of using references taken out of context, just as Shākya mchog ldan did in his time, ignoring the ritual apparatus required for full ordination. According to them, Go rams pa Bsod nams seng ge, one of the contemporary opponents of Shākya mchog ldan, is the authoritative master on the subject. They conceive the transformation from postulant to fullyordained nun ${ }^{55}$ to be valid only if the order of ordination rituals and the associated ritual procedures (cho ga) are respected: on the one hand, they refuse the idea of excusing the nuns from the two-year training period; on the other hand, they insist on the presence of fully-ordained nuns who, according to them, have an essential role in the performance of both, the tshangs spyod nyer gnas (literally 'approaching chastity') and the full ordination (bsnyen par rdzogs pa) ceremony. ${ }^{56}$

Theoretically, the two-year training period and the taking of vows that accompanies it concern only the community of dge slong ma. Under the responsibility of a preceptor (dge slob ma yi mkhan po) and after the approval of the community, the candidate, eighteen years old minimum, is received as '(female) religious trainee' (dge slob ma) and commits herself to respect the preparatory vows (dge slob ma'i sdom $\mathrm{pa}$ ) — the six 'root tenets' and six 'associated tenets'. According to Wijayaratna (1991: 45-54), who has studied the Pāli texts, this probationary period allows the candidate to receive the necessary instructions and to familiarise herself with the monastic community before taking the final decision to join the order. ${ }^{57}$

54 One of the critics, Rnam grwa Thub bstan zla wa (04/07/2007: 5), goes so far as to compare Rin chen dngos grub to Glang dar ma (r. 838-842), the Tibetan monarch who persecuted Buddhism according to tradition.

55 In Tibetan, this transformation is expressed by the terms gyur 'to transform, to change' or skye 'to be born'.

56 Cf. Rnam grwa Thub bstan zla ba (04/07/2007), Ser byes bya bral 'Jam dpal blo shor (25/07/2008; 01/08/20070; 09/08/2008), 'Bras sgo mang bya bral Chos grub (12/9/2007) and Rdza chu kha mkhan po Tshe ring bkra shis (15/08/2007).

57 Wijayaratna points out that there is only very scarce information on dge tshul ma in the Pāli texts and that this might be the case because for women the ordination of a dge slob ma was previously the equivalent of minor ordination (taking the vows of a dge tshul) for monks (1991: 53). 
The opponents stress the fact that the rules clearly stipulate the obligation of this procedure and that full ordination would no longer have any meaning if this preliminary step were skipped. They therefore support the necessity of continuity between this stage and complete ordination. Generally, Tibetan tradition emphasises the necessity of succession in both the domain of transmission of ordination lineage and in that of knowledge. In order for a lineage to be considered valid and authentic, and therefore pure, it must be continuous, that is, transmitted in an uninterrupted way (tshigs snga ma sngon du song ba, literally 'having previously gone through preliminary links'). And, as some authors underline, if one excuses nuns from the two-year training period and if the dge slong $\mathrm{ma}$ are not present, the transmission will be broken and it will not be a pure lineage of vows (sdom rgyun rnam dag).

If one follows the texts, at the end of her two-year training period, the candidate must solicit her 'female preceptor' (mkhan mo) in order to receive full ordination. If her request is agreed to, it is then necessary to assemble the ritual performers who must be made up of twelve $d g e$ slong $m a$ and ten dge slong, ${ }^{58}$ themselves ordained for a minimum of twelve and ten years respectively. The first ritual ceremony (tshangs spyod nyer gnas) involves only the presence of dge slong ma. It is an intermediate stage during which the postulant pronounces the vow of pure conduct (tshangs par spyod pa; Skt brahmacarya). Philosophically speaking, it is of the same substance as those pronounced by a dge slob ma. ${ }^{59}$ Then the same day, the dge slong join the assembly of dge slong $\mathrm{ma}$ to perform the full ordination ceremony. Three officiants occupy the role of preceptors (mkhan po; Skt upādhyāya) and seven that of ritual assistant (las slob; Skt karma ācārya), according to Thub bstan zla ba, abbot of the Rnam rgyal monastery. ${ }^{60}$ More precisely, among the preceptors, there must necessarily be a $d g e$ slong ma: the 'preceptor of the two-year training period' (dge slob ma yi mkhan po); the other two- the 'preceptor of the renunciation ceremony' (rab byung gyi mkhan po) and the 'preceptor of the full ordination' (bsnyen rdzogs kyi mkhan po)—can be either dge slong or dge

\footnotetext{
58 This quorum applies to a 'central country', that is to say, a region where the Buddhist teaching is well established; in 'borderland' countries (in relation to India), the presence of six dge slong $m a$ and five dge slong is sufficient.

59 Cf. Bod rgya tshig mdzod chen mo [Great Tibetan-Tibetan-Chinese Dictionary] (1993: 2254).

60 Rnam grwa Thub bstan zla ba (op. cit.: 5).
} 
slong ma. According to Thub bstan zla ba, among the ritual assistants two must necessarily be dge slong ma: the 'ritual assistant of dge slob $m a$ ' (dge slob ma'i las slob) and the 'ritual assistant of tshangs spyod nyer gnas' (tshangs spyod nyer gnas kyi las slob); the third-the 'ritual assistant of full vows' (bsnyen rdzogs kyi las slob)—is a dge slong.

Thub bstan zla ba also emphasises that it is not through the presence of officiating monks (pha tshogs) and nuns (ma tshogs) that the vows become real, but by their 'combined legal act' (las tshigs). More precisely, it is through the crossing (bsnol) of the two assemblies' legal acts, that the (pure) vows of a dge slong $m a$ are engendered. ${ }^{61}$

Finally, some Tibetan authors specifically oppose the feminist discourse advocated by certain Western nuns. ${ }^{62}$ They describe it as aggressive and consider it a criticism of the Buddha, and therefore destructive. ${ }^{63}$ Several of them also recall explicitly that the Buddha predicted the rapid decline of the order if women were accepted into the monastic community, alluding to his ambivalent attitude towards women.

The usefulness of the feminist discourse has also been called into question. According to Lhun grub chos ldan, ${ }^{64}$ librarian at Se ra byes, if one wants to turn the institution of female ordination into a debate on inequalities, one should take into account the number of vows-many more for women - and the 'eight heavy rules' imposed on women by the Buddha himself; but according to the same author, only a second Buddha would be able to change the rules laid down by Sākyamuni.

Finally, some say explicitly that "the idea of modernising Buddhism must come from inside and not be imposed from the outside". ${ }^{65}$

The writings of the opponents to full ordination reveal a certain ambiguity between the doctrinal reasons referred to above and those that could be described as ideological because of their opposition to the feminist discourse. It is difficult to determine the real motives of each

\footnotetext{
61 Rnam grwa Thub bstan zla ba (op. cit.: 6), citing, notably, the argument advanced by Go rams pa Bsod nams seng ge.

62 It must be made clear that the use of the feminist discourse does not mean that there is unanimity among Western nuns: several among them, notably those who follow the Theravāda tradition, refute it also. I thank Jampa Tsedroen for this information.

63 Cf. Ser byes dpe mdzod drung yig Lhun grub chos ldan (04/07/2007) and Ser byes bya bral 'Jam dpal blo shor (01/08/2007). During a conversation, G.yu thog Karma dge legs, former secretary of the Department of Religion and Culture, confirmed me that this opinion was shared by a great number of Tibetan dignitaries.

${ }^{64}$ Ser byes dpe mdzod drung yig Lhun grub chos ldan (ibid.).

65 Ser byes dpe mdzod drung yig Lhun grub chos ldan (ibid.).
} 
party. For their part, the Tibetan nuns also reject feminist ideology, which is too politicised in their eyes. At the congress of 2007 in Germany, some declared in private that they did not want to turn the debate on full ordination into a feminist issue; others expressed their satisfaction with the present conditions of religious practice. ${ }^{66}$ They even "read statements that they did not feel ready for dge slong ma ordination this time". ${ }^{67}$ This caused a feeling of annoyance among the participants, and specially the organisers ${ }^{68}$ who were convinced that their Tibetan sisters shared a common goal. ${ }^{69}$ In short, not only do Western and Tibetan nuns not agree on the reasons that motivate their demand for full ordination, but the latter seem to want at all cost to avoid a conflict with the male clergy.

\section{CONCLUSION}

The debate on the institution of full ordination for women in the Tibetan tradition, far from being closed, shows that there is little flexibility when it comes to modify the ritual prescriptions stemming from an important corpus like the vinaya. The reluctance is considerable in spite of repeated exhortations from the Dalai Lama to find a solution that will be acceptable. ${ }^{70}$ For the hierarch the opposition is due to the narrow minds of certain Tibetan dignitaries. ${ }^{71}$ In the eyes of Western nuns, the conservative dignitaries are little inclined to open Tibetan monastic hierarchy to nuns. But we can probably see in the full range of reactions a self-protective attitude: the rejection of foreign feminist ideology, just like the recourse to concepts of 'purity' and 'authenticity' of the ordination rites, show that there is a wish to preserve Tibetan

66 I would like to thank Michael Zimmermann for this information.

67 See J. Gyatso (2010: 10).

68 Kawanami (2009: 154). According to the same author many of the Tibetan nuns present at the congress could not understand the discussion since there was no Tibetan translation for the first two days. Besides, they expressed their wish to study more on the subject and to decide their own future. I would like to thank Ayako Itoh for her translation from Japanese.

69 According to Jampa Tsedroen, the organisers were told before the congress that Tibetan nuns present at the previous winter debate session had all agreed to the demand for full ordination.

70 Ser byes dpe mdzod drung yig Lhun grub chos ldan (op. cit.: 4) thinks that the part of the clergy in favour of the ordination is a minority.

71 Berzin (2007: 33). 
religious practices. We could therefore speak of an identity fallbackmainly from representatives of the dge lugs and sa skya schoolsopposing the contribution of 'modern' feminist and 'progressive' Buddhists ideas. Thus the Karmapa, who was at the beginning in favour of female ordination, explained several months after the congress:

These days many friends from abroad with a modern viewpoint are giving help and direction to Tibetan nuns and laywomen and I would like to thank them for their help. But I think we need to begin from within our own Tibetan society to find a particular Tibetan way of being modern. The reason for this is that other viewpoints and Tibetan culture are sometimes incompatible, and as Tibetan culture is already endangered, insisting too strongly on imposing other ways of doing things could very well weaken what we are working hard to preserve. ${ }^{72}$

The ambivalent attitude of Tibetan nuns shows that they have little room to manoeuvre. They know that the approval of their clergy is necessary for the achievement of female ordination. Their hesitation seems to indicate that they prefer (at least for the moment) to fall in behind their religious hierarchy, while at the same time keeping distance from their Western sisters. They seem currently to have allied themselves with the opinion of those dignitaries who want to find a solution within their tradition.

\section{POSTSCRIPT}

Several months after the congress in Germany, on 28 and 29 April 2008, the Department of Religion and Culture organised the fourth conference on female ordination. Sixteen Tibetan religious dignitaries from all Buddhist schools were invited and a few nuns from the monasteries of Dharamsala were able to attend as spectators. The discussion focused on the two methods possible for instituting full ordination. The first, which consisted of involving Chinese nuns of the Dharmaguptaka tradition, was rejected unanimously. As for the second method, which relies on Tibetan monks alone, opinions remained divided: the eight representatives of the rnying $m a$ and $b k a$ ' brgyud schools voted for and seven from the sa skya and dge lugs against; one of the dge lugs representatives abstained. ${ }^{73}$ Some months later, in October 2008, the Cabinet

\footnotetext{
72 Karmapa (2008).

73 Information from Jampa Tsedroen.
} 
of Ministers of the Tibetan government in exile ( $b k a^{\prime}$ shag) reiterated its wish to establish the lineage of dge slong $\mathrm{ma}^{74}$

\section{BIBLIOGRAPHY}

\section{References in Tibetan}

Ācārya dge bshes Thub bstan byang chub (alias Geshe Tashi Tsering), 2000a. Gzhi smra'i lugs kyi dge slong ma'i las chog gcig tu btus pa thub dbang zhal lung zhes bya $b a$, New Delhi: Indraprastha Press.

— 2000b. Bod du dge slong mar bsgrubs pa'i dpyad gzhi rab gsal me long, New Delhi: Indraprastha Press. 2000c. Dge slong ma'i 'byung khungs dpyad gzhi, New Delhi: Indraprastha Press.

'Ba' pa Skal bzang 'phrin las 'Bras blo gling, 22/08/2007. Dge bshes ma las 'phros pa'i dran rtogs thung ngu, Bod kyi bang chen 138, 3.

'Bras sgo mang bya bral Chos grub, 12/09/2007. Nga'i lta ba dang ma mthun na lta log zer gyi med, Bod kyi bang chen 141, 2.

Rdza chu kha mkhan po Tshe ring bkra shis, 15/08/2007. Dge slong ma'i skor gyi bsam gzhig, Bod kyi bang chen 137, 2.

'Jam dbyangs grags pa, 1986. Mi nyag mkhas pa'i mi lnga'i lo rgyus rags bsdus, Gangs dkar ri bo 2, 64-76.

Rnam grwa Thub bstan zla wa, 04/07/2007. Bud med bsnyen rdzogs bsgrub par dge slong pha ma gnyis tshogs tshang dgos, Bod kyi bang chen 131, 5-6.

Ser byes bya bral 'Jam dpal blo shor, 25/07/2007. Dge slong pha kho nas ma bsnyen par rdzogs chog pa'i yig don la bltas pa'i bsam 'char, Bod kyi bang chen 134, 2. 01/08/2007. Dge slong pha kho nas ma bsnyen par rdzogs chog pa'i yig don la bltas pa'i bsam 'char, Bod kyi bang chen 135, 2, 5 . 09/08/2007. Dge slong pha kho nas ma bsnyen par rdzogs chog pa'i yig don la bltas pa'i bsam 'char, Bod kyi bang chen 136, 2.

Ser byes dpe mdzod drung yig Lhun grub chos ldan, 04/07/2007. Mo chos ring lugs kyi lta ba'i rmang gzhi las byung ba, Bod kyi bang chen 131, 4 .

Ser byes lha rams ngag gi dbang phyug Rin chen dngos grub, 2007. Dge slong ma' $i \mathrm{dka}$ ' gnad brgya pa sngon med legs par bshad pa'i gter dgos 'dod kun 'byung baidurya'i phung po, Sidhpur: Tibetan Nuns Project.

Thub bstan nyi ma (ed.) 1987. Mi nyag mkhas dbang lnga'i rnam thar, Chengdu: Si khron rigs dpe skrun khang.

\section{References in Western languages}

Acharya Tashi Tsering and P. Russell 1986. An Account of the Buddhist Ordination of Women. Chö-Yang 1(1), 21-32. See also [Geshe] Tashi Tsering.

Anderson, S. 1997. Feminismus, Buddhismus und gesellschaftlicher Wandel. http://www.buddhanetz.org/texte/frauen.htm (access date October 2007).

Berzin, A. 2007. A Summary Report of the 2007 International Congress on the Women's Role in the Sangha: Bhikshuni Vinaya and Ordination Lineages

74 Cf. Central Tibetan Administration, press release of 15/10/2008. 
University of Hamburg, Hamburg, Germany 18-20 July 2007 August 2007, Part 1. http://www.berzinarchives.com/web/x/nav/eb_toc.html_1717379581.html (access date October 2007).

Central Tibetan Administration 08/12/2005. His Holiness the Dalai Lama to Inaugurate Dolma Ling Nunnery. TibetNet.

http://www.tibet.net/en/flash/2005/1205/08B1205.html (access date October 2007).

23/05/2006. His Holiness Opens Seminar on Bhikshuni Ordination of Buddhist Nuns. TibetNet. (http://www.tibet.net/en/index.php?id=1184\&articletype=flashold\&rmenuid=morenews) (access date January 2007).

15/10/2008. Kashag Outlines Policies on Women Empowerment. TibetNet http://www.tibet.net/en/index.php?id=457\&articletype=flash (access date October 2008).

Chaves, M. 1997. The Symbolic Significance of Women's Ordination. The Journal of Religion 77(1), 87-114.

Department of Religion and Culture (ed.) 2002. Concerning the Lineage of Bhikshuni Ordination: Proceedings of the Seminar of Mulasarvastivada, Theravada and Dharamagupta Vinaya Holders. New Delhi: Indraprastha Press.

Diemberger, H. 2007. When a Woman Becomes a Religious Dynasty: The Samding Dorje Phagmo of Tibet. New York: Columbia University Press.

Gellner, D. and S. LeVine 2005. Rebuilding Buddhism: The Theravada Movement in Twentieth-Century Nepal. Cambridge, MA: Harvard University Press.

Gross, R. 1981. Feminism from the Perspective of Buddhist Practice. BuddhistChristian Studies 1, 73-82.

Gyatso, J. 2010. Female Ordination in Buddhism: Looking into a Crystal Ball, Making a Future. In T. Mohr and Jampa Tsedroen (eds), Dignity and Discipline. Reviving Full Ordination for Buddhist Nuns. Boston: Wisdom Publications, 1-22.

Havnevik, H. 1995. Combats des nonnes tibétaines. Paris: Dharma.

Horner, I.B. 1930 [1989]. Women under Primitive Buddhism: Laywomen and Almswomen. New Delhi: Motilal Banarsidass Publishers.

Jampa Tsedroen 2008. Generation to Generation: Transmitting the Bhikṣunī Lineage in the Tibetan Tradition. In Karma Lekshe Tsomo (ed.) Buddhist Women in a Global Multicultural Community. Kuala Lumpur: Sukhi Hotu Publications, 205-215.

Karma Lekshe Tsomo (ed.) 1988. Daughters of the Buddha. Ithaca, NY: Snow Lion Publications.

(ed.) 1995. Buddhism Through American Women's Eyes. Ithaca, NY: Snow Lion Publications.

1997. Sisters in Solitude. Two Traditions of Buddhist Monastic Ethics for Women: A Comparative Analysis of the Chinese Dharmagupta and the Tibetan Mūlasarvāstivāda Bhikṣuñ̄ Prātimokṣa Sūtras. Delhi: Sri Satguru Publications. (ed.) 1999. Innovative Buddhist Women: Swimming against the Stream. Richmond: Curzon.

(ed.) 2000. Buddhist Women Across Cultures. New Delhi: Sri Satguru Publications.

(ed.) 2004a. Bridging Worlds: Buddhist Women's Voices Across Generations. Taipei: Yuan Chuan Press.

(ed.) 2004b. Buddhist Women and Social Justice: Ideals, Challenges, and Achievements. Albany, NY: State University of New York Press. (ed.) 2004c. Discipline and Practice: Buddhist Women Past and Present. Honolulu: Sakyadita. 
_ed.) 2006. Out of the Shadows: Socially Engaged Women. Delhi: Sri Satguru Publications.

(ed.) 2008. Buddhist Women in a Global Multicultural Community. Kuala Lumpur: Sukhi Hotu Publications.

Karmapa 2008. Nun's Education and Conduct in Modern Times. URL : h t t p : / / w w w . kag y u office . org/Pas t A c t i vit i e s-0 9JantoMarch.html\#NunsEducationandConductinModernTimes (access date mai 2010).

Kawanami, H. 2009. Bukkyô wo hiraku asia no josei tachi [Asian women who pioneer Buddhism]. In Kokusai shûkyô kenkûjo [International Institute for the Study of Religions] (ed.) Gendai Shûkyô. Henkaku ki no asia to shûkyô [Contemporary Religion. Asia and Religion in Change], 132-163.

Li, Y. 1999. Ordination, Legitimacy, and Sisterhood. In Karma Lekshe Tsomo (ed.) Innovative Buddhist Women: Swimming against the Stream. Richmond: Curzon, 168-198.

Martin, D. 2005. The Woman Illusion? Research into the Lives of Spiritually Accomplished Women leaders of the $11^{\text {th }}$ and $12^{\text {th }}$ Centuries. In J. Gyatso and $\mathrm{H}$. Havnevik (eds) Women in Tibet. London: Hurst and Co., 49-82.

Mohr, T. and Jampa Tsedroen 2010. Dignity and Discipline. Reviving Full Ordination for Buddhist Nuns. Boston: Wisdom Publications.

Seele-Nyima, C. 2001. Tibetische Frauen zwischen Tradition und Innovation. Eine Untersuchung zum soziokulturellem Wandel im indischen Exil. Hamburg: LITVerlag.

Smith, G. 2001. Among Tibetan Texts. History and Literature of the Himalayan Plateau. Boston: Wisdom Publications.

Tashi Tsering, Geshe 2010. A Lamp of Vinaya Statements: A Concise Summary of Bhikṣunī Ordination (original title: 'Dul ba'i lung gi sgron mel dge slong ma' $i$ skor nyams zhib snying bsdus nyung gsal, 2007, translated into English by Dr Ckok Tenzin Monlam and revised subsequently by the editors). In T. Mohr and Jampa Tsedroen (eds) Dignity and Discipline. Reviving Full Ordination for Buddhist Nuns. Boston: Wisdom Publications, 161-182.

Thubten Chodron 1994. L'évolution du bouddhisme en Occident: un regard féminin. Actualités tibétaines 5(1), 39.

- 2010. A Tibetan Precedent for Multi-tradition Ordination. In T. Mohr and Jampa Tsedroen (eds) Dignity and Discipline. Reviving Full Ordination for Buddhist Nuns. Boston: Wisdom Publications, 183-194.

Wijayaratna, M. 1991. Les moniales bouddhistes: naissance et développement du monachisme féminin. Paris: Cerf.

Wurst, R. 1999. Aufgaben und Zielsetzungen von Sakyadhita im Westen. Journal of Religious Culture, 27-12 (http://web.uni-frankfurt.de/irenik/relkultur27-12.html) (access date October 2007).

\section{Dictionaries}

Bod rgya tshigs mdzod chen mo 1993. Beijing: mi rigs dpe skrun khang, 2 volumes. Tsepak Rigzin 1997. Tibetan-English Dictionary of Buddhist Terminology (Revised and Enlarged Edition). Dharamsala: Library of Tibetan Works and Archives. 